\title{
MICROPROPAGATION OF LILIUM CANDIDUM L. : A RARE AND NATIVE BULBOUS FLOWER OF TURKEY
}

\author{
Betül BuRUn* ANd ORAL SAHIN ${ }^{1}$ \\ Department of Biology, Faculty of Science, Muğla Sitki Kçman University, Muğla, Turkey
}

Key words: Micropropagation, Lilium candidum, Flower bulbs, Plant growth regulators

\begin{abstract}
Lilium candidum bulb scales were cultured on MS containing different doses and combinations of NAA, $\mathrm{BA}, \mathrm{Kn}$ and 2iP. Maximum bulblet formation was $88.2 \%$ in MS supplemented with $0.1 \mathrm{mg} / 1 \mathrm{NAA}+0.01$ $\mathrm{mg} / \mathrm{l} \mathrm{BA}$ and the average number of bulblets per explant was 2.9.
\end{abstract}

Turkey is very rich in bulbous, rhizome and tuberous plants (geophytes) in line with its overall crop wealth. Six different species of the genus Lilium grow in Turkey. Lilium candidum L., one of these species, is a rare plant and grows in south west Anatolia, Turkey (Davis 1984). Genus Lilium is commonly used as cut flower and L. candidum has also been used as with aromatic and ornamental plants and exported for years, but it is now an endangered plant (in the category of vulnerable plants-VU) because of excessive collection from the wild (Ekim et al. 2000). There exists only a few report on in vitro production of L. candidum (Khawar et al. 2005a, Khawar et al. 2005b). So, the present research was undertaken to study the micropropagation of wild $L$. candidum.

Generally, in micropropagation of flower bulbs, it is noted that a low concentration of auxin promotes the formation of plantlets and cytokinins stimulate the number of plantlets. Besides, high concentrations of MS salts, vitamins and additional sucrose have positive effects and compared to the concentration used for other plants. According to present observation, optimum temperature also varies. There are reports that light has both promoting and preventative effects (Aartrijk and Van der Linde 1986).

Bulb scales of $L$. candidum cultured in this study were collected from the natural habit Dalyan-Muğla region. In addition, for comparison, bulb scale explants of Lilium longiflorum Thunb. (culture form) were also cultured in vitro. Bulb scales cut in width (5 - $7 \mathrm{~mm}$ parts, basal, middle and distal explants). Explants were cultured on MS medium (Murashige and Skoog 1962) containing different doses and combinations of NAA, BA, Kn and 2iP. Sucrose $30 \mathrm{~g} / \mathrm{l}$ was added, $\mathrm{pH}$ was adjusted to 5.5 and then $6 \mathrm{~g} / \mathrm{l}$ agar was added. Cultures were incubated for $8 \mathrm{~h}$ dark and 16 $\mathrm{h}$ daylight under a 1600 lux light. The average temperature was $20-22{ }^{\circ} \mathrm{C}$ and humidity was $50 \%$ during culture. The sterilization method of Stimart et al. (1980) was modified to sodium hypocholoride solution concentration in doses of 1 and $2 \%$ for $20 \mathrm{~min}$. Experiment is planned as two replicates related to the factorial experimental design and evaluated with the help of SAS statistical program.

When bulb scales were sterilized by the method given by Stimart et al. (1980), the infection rate was found high. When $2 \%$ sodium hypocholoride was applied, decrease in the infection was observed (average $38.3 \%$ in L. candidum and $19.1 \%$ in L. longiflorum).

The bulb scale explants cultured on MS supplemented with different plant growth regulators formed direct bulblet. Both bulblet formation and rooting on the bulb scale explants cultured on MS supplemented with only $0.1 \mathrm{mg} / 1$ NAA were observed. But in many explants $(40 \%)$ only rooting could be observed. 
In MS supplemented with $0.1 \mathrm{mg} / \mathrm{l} \mathrm{NAA}+0.01 \mathrm{mg} / \mathrm{l} \mathrm{BA}$, bulblet formation was observed in all explants (basal, middle, distal parts of bulb scale) (average 88.2\%), but the highest bulblet formation and rooting was in the basal and middle parts (100\%). Almost all the developed bulblets had leaves and rooting was normal. Maximum 8 bulblets per explants were obtained from middle parts explants of $L$. candidum (average number of bulblets per explant 2.9) and 7 bulblets from $L$. longiflorum basal part. Rooting and bulblet formation was observed in all explants (average $86.3 \%$ ) in the medium supplemented with $0.1 \mathrm{mg} / 1 \mathrm{NAA}+0.01 \mathrm{mg} / \mathrm{Kn}$. The number of bulblets obtained per explant was maximum 3 for $L$. candidum with an average value of 2.0 and 1.5, respectively.

Generally, bulblets were formed on the basal parts of bulb scales in the MS supplemented with $1.0 \mathrm{mg} / 12 \mathrm{iP}$. Rooting rate without bulblets was $20 \%$ for $L$. longiflorum. There was bulblet formation average of $82.9 \%$ in in the MS supplemented with $0.1 \mathrm{mg} / 1 \mathrm{NAA}+1.0 \mathrm{mg} / \mathrm{l} 2 \mathrm{iP}$. But higher rooting was seen although bulblet development was very poor.

In vitro development was better for $L$. longiflorum than $L$. candidum in all MS media supplemented with plant growth regulators in different combinations. In L. candidum bulblet formation was different from explants according to plant growth regulator dose and combinations but in L. longiflorum all plant growth regulator dose and combinations was not significant statistically (Table 1).

Table 1. Bulblet formation (\%) from bulb scale explants in MS supplemented with plant growth regulators in different combinations.

\begin{tabular}{lll}
\hline Media & Lilium candidum & Lilium longiflorum \\
\hline MS + 0.1 mg/1 NAA & $62.5 \mathrm{~b}$ & $95.8 \mathrm{a}$ \\
$\mathrm{MS}+0.1 \mathrm{mg} / 1 \mathrm{NAA}+0.01 \mathrm{mg} / 1 \mathrm{BA}$ & $88.2 \mathrm{a}$ & $95.4 \mathrm{a}$ \\
$\mathrm{MS}+0.1 \mathrm{mg} / 1 \mathrm{NAA}+0.01 \mathrm{mg} / 1 \mathrm{Kn}$ & $86.3 \mathrm{ab}$ & $84.6 \mathrm{a}$ \\
$\mathrm{MS}+1.0 \mathrm{mg} / 1 \mathrm{iP}$ & $69.0 \mathrm{ab}$ & $84.4 \mathrm{a}$ \\
$\mathrm{MS}+0.1 \mathrm{mg} / 1 \mathrm{NAA}+1.0 \mathrm{mg} / 12 \mathrm{iP}$ & $82.9 \mathrm{ab}$ & $89.4 \mathrm{a}$ \\
\hline
\end{tabular}

Data having the same letter in a column were not significantly differed by Duncan's multiple comparison test $(\mathrm{p}<0.05)$.

L. longiflorum was cultured in Linsmaer-Skoog medium supplemented with $0.003 \mathrm{mg} / \mathrm{l} \mathrm{NAA}$ by Stimart and Ascher (1978). Number and size of bulblets increased at $25^{\circ} \mathrm{C}$ in dark and for bulb formation NAA was very useful.

Khawar et al. (2005a) achieved mass proliferation from the half bulb scales of $L$. candidum using various concentrations of BAP-IBA. MS medium containing $2.22 \mu \mathrm{M}$ BA and $2.69 \mu \mathrm{M}$ NAA was found effective (Khawar et al. 2005b).

In the present investigation, it was found that in vitro propagation with bulb scales of $L$. candidum and L. longiflorum cytokinin together with NAA into low concentrations required an addition of culture medium. Bulblet development from basal, middle and distal explants obtained by cuttting bulb scales in width for in vitro culture of $L$. candidum bulb scales was also observed.

\section{Acknowledgement}

This work was supported financially by the Research Fund of Muğla Sitkı Koçman University. The authors are grateful for financial support. 


\section{References}

Aartrijk JV and Van der Linde PCG 1986. In vitro propagation of flower-bulb crops. In: Tissue culture as a plant production system for horticultural crops (Zimmerman RH Ed.), pp.317-331. Martinus Nijhoff Publishers, Dordrecht, Printed in The Netherlands.

Davis PH 1984. Flora of Turkey and the East Aegean Island. Edinburgh University Press, Vol. 8, pp. 280281.

Ekim T, Koyuncu M, Vural M, Duman H, Aytaç Z and Adıgüzel N 2000. Red data book of Turkish plants: Pteridophyta and Spermatophyta. Türkiye Tabiatını Koruma Derneği, Van Yüzüncü Y1l Üniversitesi, Ankara.

Khawar KM, Cocu S, Parmaksız I, Sarihan EO and Ozcan S 2005a. Mass proliferation of madonna lily (Lilium candidum L.) under in vitro conditions. Pak. J. Bot. 37(2): 243-248.

Khawar KM, Sancak C, Ozcan S, Sarihan EO, Parmaksız I, Sevimay CS and Cocu S 2005b. Prolific in vitro bulblet formation from bulb scales of meadow lily (Lilium candidum L.). Period. Biol. 107(1): 107-111.

Stimart DP and Ascher PD 1978. Tissue culture of bulb scale sections for asexual propagation of Lilium longiflorum Thunb. J. Amer. Hort. Sci. 103(2): 182-184.

Stimart DP, Ascher PD and Zagorski JS 1980. Plants from callus of the interspecific hybrid Lilium 'Black Beauty'. HortScience 15(3): 313-315.

(Manuscript received on 15 September, 2012; revised on 16 February, 2013) 